\title{
Problem „związania” decyzją o środowiskowych uwarunkowaniach
}

1. Wydawana na podstawie przepisów ustawy z dnia 3 października $2008 \mathrm{r}$. o udostępnianiu informacji o środowisku i jego ochronie, udziale społeczeństwa w ochronie środowiska oraz o ocenach oddziaływania na środowisko ${ }^{1}$ decyzja o środowiskowych uwarunkowaniach stanowi podstawowy instrument umożliwiający przeprowadzenie oceny oddziaływania na środowisko. Akt ten stanowi swego rodzaju zezwolenie na realizację przedsięwzięcia i określa najczęściej jego środowiskowe uwarunkowania.

Konstrukcja polskiego modelu ocen oddziaływania na środowisko, oparta na wspomnianej decyzji, jest szczególna. „Odłączono” bowiem procedury oceny od postępowania w sprawie wydania pozwolenia na realizację konkretnego zamierzenia. Inaczej mówiąc, obowiązujący w naszym kraju system zakłada w analizowanym zakresie dwa odrębne postępowania. Pierwsze, to przeprowadzenie oceny oddziaływania na środowisko. Jego wynikiem jest decyzja środowiskowa. W niej, ,zakodowane” zostaną wyniki przeprowadzonej oceny. We wspomnianej decyzji organ administracji musi zawrzeć wyniki swojego postępowania, formułując jednocześnie warunki, pod którymi przedsięwzięcie może zostać zrealizowane. Drugi etap to „odkodowanie” powyższych informacji (warunków) i zamieszczenie ich przez właściwy organ w pozwoleniu na realizację zamierzenia $^{2}$.

${ }^{1}$ Dz.U. 2021 r. poz. 247.

${ }^{2}$ Szerzej na ten temat patrz G. Dobrowolski, Decyzja o środowiskowych uwarunkowaniach, Towarzystwo Naukowe Organizacji i Kierownictwa „Dom Organizatora”, Toruń 2011, s. $106-$ 264; M. Pchałek, M. Behnke, Postepowanie w sprawie oceny oddziatywania na środowisko w prawie polskim i UE, Wydawnictwo C.H.Beck, Warszawa 2009, s. 57-223; Z. Wiśniewski, 
Rozdzielenie procedur oceny oddziaływania na środowisko oraz wydawania pozwolenia na realizację przedsięwzięcia powoduje szereg wątpliwości interpretacyjnych. Do najważniejszej należy zaliczyć zakres (przedmiotowy i podmiotowy) związania decyzją, o której mowa w art. 71 ustawy o ocenach. Problem sprowadza się do odpowiedzi, kto i w jakim zakresie jest związany środowiskowymi uwarunkowaniami realizacji przedsięwzięcia.

2. Zakres związania decyzją o środowiskowych uwarunkowaniach określa zasadniczo art. 86 ustawy o ocenach. Pierwotnie stanowił on, że „decyzja o środowiskowych uwarunkowaniach wiąże organ wydający decyzje, o których mowa w art. 72 ust. 1"'. Przepis powyższy, pomimo swojej prostoty, budził znaczące wątpliwości interpretacyjne. Dotyczyły one zakresu owego związania oraz kręgu pomiotów zobowiązanych ${ }^{4}$.

Istotna zmiana art. 86 ustawy nastąpiła na mocy ustawy z dnia 9 października 2015 r. o zmianie ustawy o udostępnianiu informacji o środowisku i jego ochronie, udziale społeczeństwa w ochronie środowiska oraz o ocenach oddziaływania na środowisko oraz niektórych innych ustaw ${ }^{5}$. Rozszerzono wówczas „podmiotowy” zakres związania decyzją o środowiskowych uwarunkowaniach. Poza organami wydającymi jedną z decyzji, o których mowa w art. 72 ust. 1 ustawy, pojawiły się organy:

- wydające decyzje określające warunki korzystania ze środowiska w zakresie, w jakim ma być uwzględniona przy wydawaniu tych decyzji;

- przyjmujące zgłoszenia, o których mowa w art. 72 ust. 1a.

Określenie „decyzje określające warunki korzystania ze środowiska” nie jest precyzyjne. Literalne brzmienie powyższego sformułowania wskazywałoby, że chodzi tu o wszelkie decyzje, które określają „,sposób” korzystania ze środowiska. W takim rozumieniu związanie decyzją środowiskową dotyczyłoby reglamentacyjnych instrumentów ochrony środowiska (przede wszystkim pozwoleń emisyjnych) ${ }^{6}$, ale również instrumentów odpowiedzialności administracyjnej. Wyjątkiem byłyby oczywiście te decyzje, które „określają” warunki korzystania

Decyzja o środowiskowych uwarunkowaniach w świetle orzecznictwa sadowoadministracyjnego i standardów unijnych, w: Europeizacja prawa ochrony środowiska”, red. M. Rudnicki, A. Haładyj, K. Sobieraj, Wydawnictwo KUL, Lublin 2011, s. 85-118.

${ }^{3}$ Pierwotnie ,art. 72 ust. 1 pkt 1-13”. Przy kolejnych nowelizacjach i poszerzaniu katalogu zawartego w art. 72 ust. 1 ustawy prawodawca zdecydował się zrezygnować z podawania ilości jednostek redakcyjnych (punktów) znajdujących się w tym ustępie.

${ }^{4}$ G. Dobrowolski, Decyzja..., s. 288-292. Por. także P. Otawski: Decyzja o środowiskowych uwarunkowaniach - relacja do innych decyzji w toku realizacji i eksploatacji przedsięwzięcia, w: Proces inwestycji budowlanych, red. A. Plucińska-Filipowicz, M. Wierzbowski, Wolter Kluwer, Warszawa 2015, s. 193-206.

${ }^{5}$ Dz.U. poz. 1936.

${ }^{6}$ Tak prawdopodobnie D. Trzcińska, Charakter prawny decyzji o środowiskowych uwarunkowaniach zgody na realizację przedsięwzięcia, „Studia Prawnoustrojowe” 2017, nr 37, s. 78. 
ze środowiska i zostały wymienione w art. 72 ust. 1 ustawy o ocenach ${ }^{7}$. W ten sposób decyzja o środowiskowych uwarunkowania staje się „,superaktem” ustalającym wszelkie możliwe oddziaływanie podmiotu korzystającego ze środowiska na otoczenie, wiążącym jednocześnie organy administracji wydające inne (niż wymienione w art. 72 ust. 1 ustawy o ocenach) decyzje w analizowanym zakresie.

Można również podnieść argumentację odmienną. Należy odpowiedzieć sobie na pytanie, czym jest decyzja o środowiskowych uwarunkowaniach i jaką rolę pełni w procesie inwestycyjnym. Jest to akt określający środowiskowe warunki realizacji przedsięwzięcia (art. 71 ust. 1 ustawy o ocenach) stanowiący jednocześnie zgodę na jego podjęcie. Przedsięwzięcie stanowi zaś (art. 3 ust. 1 pkt 13 ustawy o ocenach), ,zamierzenie budowlane lub inną ingerencję w środowisko polegającą na przekształceniu lub zmianie sposobu wykorzystania terenu, w tym również na wydobywaniu kopalin; przedsięwzięcia powiązane technologicznie kwalifikuje się jako jedno przedsięwzięcie, także jeżeli są one realizowane przez różne podmioty". Nie budzi zatem wątpliwości to, że związanie decyzją środowiskową dotyczy etapu inwestycyjnego (realizacji przedsięwzięcia). Wydawanie decyzji określających warunki korzystania ze środowiska to zaś zupełnie inny etap działalności. W odniesieniu do tych ostatnich aktów zostały, w poszczególnych ustawach, wskazane szczegółowe przesłanki ich wydawania — jak choćby w przypadku pozwoleń zintegrowanych w art. 201-208 ustawy Prawo ochrony środowiska.

Powyższą tezę zdają się potwierdzać uzasadnienia projektu noweli. Druk sejmowy nr 3677 Sejmu VII kadencji zawiera sformułowanie, że ,zmiana w art. 86 dotyczy wskazania, że decyzja o środowiskowych uwarunkowaniach wiąże organy wydające decyzje, o których mowa w art. 72 ust. 1, i przyjmujące zgłoszenia, o których mowa w art. 72 ust. 1a oraz — w zakresie, w jakim ma być uwzględniona przy wydawaniu tych decyzji — decyzje określające warunki korzystania ze środowiska. Wprowadzenie regulacji w tym zakresie jest uzasadnione w związku z prewencyjnym charakterem dyrektywy 2011/92/UE". Chodzi tu oczywiście o dyrektywę Parlamentu Europejskiego i Rady z dnia 13 grudnia 2011 r. w sprawie oceny skutków wywieranych przez niektóre przedsięwzięcia publiczne i prywatne na środowisko ${ }^{8}$. Akt ten przewiduje w pewnym zakresie możliwość integracji procedur oceny oddziaływania na środowisko

7 Pośrednio takie stanowisko zdaje się zajmować WSA w Warszawie w wyroku z dnia 27 października 2017 r. (sygn. akt IV SA/Wa 339/17 — wszystkie orzeczenia za CBOSA), stwierdzając: „dokonując takiej analizy pomiędzy decyzjami środowiskowymi a pozwoleniem zintegrowanym nie występują różnice, które stanowiłyby naruszenie art. 86 ustawy ocenowej (jedyną różnicą jest prowadzenie całego procesu kompostowania w hali, co jest rozwiązaniem korzystniejszym dla środowiska, aniżeli ten wskazany w decyzji środowiskowej z 2012 r.”.

${ }^{8}$ Dz.Urz. UE L 26 z dnia 28 stycznia 2012 r., s. 1-21. 
planowanych przedsięwzięć (art. 2 dyrektywy) ${ }^{9} \mathrm{z}$,innymi” procedurami wydawania zezwoleń na realizację przedsięwzięcia lub procedurami wydawania pozwoleń zintegrowanych. Jednakże w tym ostatnim zakresie w Polsce do takiej integracji nie doszło. Brak zatem podstaw do dość przypadkowego łączenia decyzji określającej środowiskowe uwarunkowania z procedurą wydawania pozwolenia zintegrowanego (czy też innego „emisyjnego").

Jeszcze większe wątpliwości budzi zawarte w uzasadnieniu noweli wyjaśnienie zmiany art. 83 ustawy o ochronie przyrody. Wskazano tam, że zmiana powyższa wynika ze zmiany art. 86 ust. 1 ustawy o ocenach odnośnie decyzji określających „warunki korzystania ze środowiska w zakresie, w jakim ma być uwzględniona przy wydawaniu tych decyzji”. „W związku z przewidzianą w dyrektywie 2011/92/UE koordynacją ocen dodano w art. 83 ust. 10 ustawy o ochronie przyrody przepis, przewidujący podstawę do uwzględnienia warunków wynikających z decyzji o środowiskowych uwarunkowaniach - jeżeli zostały w niej przewidziane - dotyczących usunięcia drzew lub krzewów w pozwoleniu na usunięcie drzew lub krzewów planowanych w ramach danego przedsięwzięcia. Zmiana ta ma na celu koordynację obydwu postępowań wówczas, gdy decyzja o środowiskowych uwarunkowaniach odnosi się do materii będącej przedmiotem postępowania $\mathrm{w}$ sprawie pozwolenia na wycinkę drzew lub krzewów. Ze względu na fakt, iż w zależności od rodzaju przedsięwzięcia mogą istnieć różnice $\mathrm{w}$ zakresie szczegółowości warunków dotyczących wycinki drzew lub krzewów, dodano zastrzeżenie, że przepis ten ma zastosowanie, jeśli warunki te zostały przewidziane $\mathrm{w}$ decyzji o środowiskowych uwarunkowaniach". Co ciekawsze, uchwalona wersja noweli żadnej zmiany art. 83 ustawy o ochronie przyrody nie zawiera.

Podniesione wyżej wątpliwości mogą falsyfikować twierdzenie, iż art. 86 ust. 1 pkt 1 stanowi podstawę uwzględniania treści decyzji o środowiskowych uwarunkowaniach przy wydawaniu pozwoleń „emisyjnych”. Zapewne kwestia ta zostanie rozstrzygnięta $\mathrm{w}$ orzecznictwie sądów administracyjnych.

Najmniej wątpliwości budzi „związanie” przyjmujące zgłoszenia, o których mowa $\mathrm{w}$ art. 72 ust. 1a, wprowadzone w związku z poszerzeniem możliwości budowy, wykonania robót budowlanych, a ostatecznie także zgłoszenia zmiany sposobu użytkowania obiektu budowlanego lub jego części na podstawie ustawy z dnia 7 lipca 1994 r. — Prawo budowlane.

${ }^{9}$ Zgodnie z art. 2 ust. 2 dyrektywy „ocena oddziaływania na środowisko może być zintegrowana $\mathrm{z}$ istniejącymi procedurami udzielania zezwolenia na przedsięwzięcia $\mathrm{w}$ państwach członkowskich lub, jeżeli takie nie istnieją, z innymi procedurami albo z procedurami, które będą ustanowione do realizacji celów niniejszej dyrektywy”. Ustęp 3 stanowi zaś że „Państwa członkowskie mogą przewidzieć stosowanie jednolitej procedury w celu spełnienia wymogów niniejszej dyrektywy i wymogów dyrektywy Parlamentu Europejskiego i Rady 2008/1/WE z dnia 15 stycznia 2008 r. dotyczącej zintegrowanego zapobiegania zanieczyszczeniom i ich kontroli". 
Nowela z 2015 r. dokonała jeszcze dwóch istotnych zmian w zakresie mocy wiążącej decyzji o środowiskowych uwarunkowaniach. Pierwsza, to wprowadzenie egzekucji (w trybie przepisów o postępowaniu egzekucyjnym w administracji) wykonania warunków decyzji o środowiskowych uwarunkowaniach nieuwzględnionych w decyzjach, o których mowa w art. 86 ustawy, o ile przedsięwzięcie jest realizowane (nowy art. $86 \mathrm{c}$ ustawy o ocenach).

Przewidziano również nakładanie przez wojewódzkiego inspektora ochrony środowiska kary pieniężnej za niedopełnienie niektórych obowiązków nałożonych decyzją o środowiskowych uwarunkowaniach. I tak w analizowanym zakresie dotyczy to (art. 136a ustawy o ocenach):

- naruszenia warunków, wymogów oraz obowiązków w zakresie istotnych warunków korzystania ze środowiska $\mathrm{w}$ fazie realizacji i eksploatacji lub użytkowania przedsięwzięcia, ze szczególnym uwzględnieniem konieczności ochrony cennych wartości przyrodniczych, zasobów naturalnych i zabytków oraz ograniczenia uciążliwości dla terenów sąsiednich ${ }^{10}$,

- niewykonania kompensacji przyrodniczej,

- niepodjęcia, określonych w decyzji, obowiązków w zakresie unikania, zapobiegania,

- niepodjęcia, określonego w decyzji, monitorowania oddziaływania przedsięwzięcia na środowisko oraz związanych z tym obowiązków informacyjnych, - nieprzedstawienia analizy porealizacyjnej.

Powyższa odpowiedzialność administracyjna może wystąpić oczywiście tylko w przypadku, gdy przedsięwzięcie jest realizowane. Czyli na podstawie decyzji o środowiskowych uwarunkowaniach musi zostać wydana jedna z decyzji, o których mowa w art. 72 ust 1 ustawy o ocenach, albo zgłoszenie, o którym mowa w art. 72 ust. 1a, oraz muszą zostać faktycznie podjęte działania w celu realizacji zamierzenia.

Pojawia się wreszcie pytanie, czy art. 136a ustawy o ocenach znajdzie zastosowanie w odniesieniu do decyzji o środowiskowych uwarunkowaniach niepoprzedzonej oceną oddziaływania na środowisko. Zgodnie z art. 84 ust. 1 ustawy o ocenach „w przypadku gdy nie została przeprowadzona ocena oddziaływania przedsięwzięcia na środowisko, w decyzji o środowiskowych uwarunkowaniach właściwy organ stwierdza brak potrzeby przeprowadzenia oceny oddziaływania przedsięwzięcia na środowisko. Decyzja ta wydawana jest po uzyskaniu opinii, o których mowa w art. 64 ust. 1 i la". Jednakże zgodnie z ust. la tego artykułu „w decyzji, o której mowa w ust. 1, właściwy organ może określić warunki lub wymagania, o których mowa w art. 82 ust. 1 pkt 1 lit. b lub c, lub nałożyć obowiązek działań, o których mowa w art. 82 ust. 1 pkt 2 lit. b lub c". Redakcja powyższego przepisu („,może określić warunki lub wymagania, o których

${ }^{10}$ Analiza treści art. 136a ust. 1 pkt 1 ustawy o ocenach wskazuje jednak, że dotyczy to jedynie fazy realizacji przedsięwzięcia. 
mowa [...]") wskazuje, że również w tym przypadku brak realizacji niektórych obowiązków nałożonych w decyzji o środowiskowych uwarunkowaniach może skutkować nałożeniem kary pieniężnej.

3. Należy przyjąć, że użyte w art. 86 ustawy o ocenach określenie „wiąże” oznacza konieczność uwzględnienia wymagań określonych w decyzji o środowiskowych uwarunkowaniach w związku z wydawaniem zezwoleniem realizacji przedsięwzięcia ${ }^{11}$. Kluczową rolę odgrywa oczywiście samo ustalenie tych wymagań, czyli faktyczna zgoda na realizację przedsięwzięcia. Wydanie decyzji negatywnej (odmawiającej ustalenia uwarunkowań — bądź ,zgody na realizację przedsięwzięcia") uniemożliwia uzyskanie pozwolenia na realizację zamierzenia $^{12}$. Decyzja o środowiskowych uwarunkowaniach ma dostarczyć wiążących informacji dla organów orzekających na kolejnym etapie realizacji inwestycji celem skonkretyzowania wymagań ochrony środowiska. Organ orzekający o środowiskowych uwarunkowaniach danego przedsięwzięcia ma więc obowiązek kierować się wynikającą z art. 6 ustawy Prawo ochrony środowiska zasadą przezorności, obligującą do przewidzenia wszystkich skutków ingerencji w środowisko na etapie realizacji i eksploatacji planowanej inwestycji ${ }^{13}$. Analizowane związanie odnosi się do charakterystycznych parametrów danej inwestycji i jej oddziaływania na środowisko, nie zaś do wyznaczonego obszaru oddziaływania przedsięwzięcia na potrzeby prowadzonego postępowania ${ }^{14}$.

Szczegółowej analizy zakresu związania decyzją o środowiskowych uwarunkowaniach najprościej dokonać w oparciu o treść art. 82 ustawy o ocenach. Przepis ten określa bowiem treść wspomnianego aktu.

Decyzja o środowiskowych uwarunkowaniach określa przede wszystkim rodzaj i lokalizację przedsięwzięcia ${ }^{15}$ (art. 82 ust. 1 pkt 1 lit. a ustawy o oce-

11 Problematyka związania decyzją administracyjną łączy się z zagadnieniem wykonalności tego aktu. W odniesieniu do decyzji o środowiskowych uwarunkowaniach zob. A. Kosieradzka-Fedrczyk, Decyzje o środowiskowych uwarunkowaniach oraz ich wykonalność $i$ wykonanie. Analiza prawna, „Przegląd Prawa Ochrony Środowiska” 2013, nr 2, s. 47-67.

12 Szerzej na ten temat patrz G. Dobrowolski, A. Lipiński, R. Mikosz, G. Radecki, Gospodarowanie geologicznymi zasobami środowiska w świetle zasady zrównoważonego rozwoju. Zagadnienia prawne, Wydawnictwo Uniwersytetu Śląskiego, Katowice 2018, s. 157-159.

13 Por. wyrok WSA w Poznaniu z dnia 7 lutego 2018 r. (sygn. akt IV SA/Po 292/15). Por. także P. Sadowski, D. Lebowa, Administracyjnoprawne ograniczenia realizacji przedsięwzięć wynikające z konieczności uzyskania decyzji środowiskowej, w: „Annales Universitatis Mariae Curie-Skłodowska, sectio G (Ius)" 2017, nr 1, s. 131.

14 Por. wyrok WSA w Rzeszowie z dnia 9 maja 2018 r. (sygn. akt II SA/Rz 1177/17).

$15 \mathrm{~W}$ przypadku inwestycji w zakresie terminalu oraz strategicznej inwestycji w sektorze naftowym miejsce realizacji przedsięwzięcia określa się za pomocą mapy w skali zapewniającej czytelność przedstawionych danych, z zaznaczonym przewidywanym terenem, na którym będzie realizowane przedsięwzięcie, stanowiącej załącznik do decyzji. 
nach). Określenie rodzaju przedsięwzięcia będzie polegało na jego wskazaniu, zgodnie z nomenklaturą stosowaną w § 2 i 3 rozporządzenia Rady Ministrów z dnia z dnia 10 września 2019 r. w sprawie przedsięwzięć mogących znacząco oddziaływać na środowisko ${ }^{16}$. Wskazanie zaś miejsca realizacji przedsięwzięcia powinno nastąpić przez podanie nazwy miejscowości (nazwy ulicy) oraz numerów ewidencyjnych działek, na których ma być realizowane przedsięwzięcie ${ }^{17}$. Należy przyjąć, że w powyższym zakresie przedsięwzięcie wskazane w pozwoleniu na jego realizację musi być tożsame z określonym w decyzji o środowiskowych uwarunkowaniach.

Organ wydający pozwolenie na realizację przedsięwzięcia jest zobowiązany, o ile to możliwe, do uwzględnienia warunków wykorzystywania terenu w fazie realizacji i eksploatacji lub użytkowania przedsięwzięcia, ze szczególnym uwzględnieniem konieczności ochrony cennych wartości przyrodniczych ${ }^{18}$, zasobów naturalnych i zabytków oraz ograniczenia uciążliwości dla terenów sąsiednich. W tym zakresie związanie środowiskowe uwarunkowania należy traktować jako ustalenie okoliczności faktycznych, które będzie musiał wziąć pod uwagę, kształtując treść rozstrzygnięcia. Część z nich zapewne będzie możliwe do ,inkorporowania” do pozwolenia na realizację przedsięwzięcia. Przykładem mogą tu być:

- art. 54 pkt 2 ustawy z dnia 27 marca 2003 r. o planowaniu i zagospodarowaniu przestrzennym ${ }^{19}$ przewidujący, że decyzja o lokalizacji inwestycji celu publicznego określa m.in. warunki i szczegółowe zasady zagospodarowania terenu oraz jego zabudowy wynikające z przepisów odrębnych;

- art. 30 ust. 2 ustawy z dnia 9 czerwca 2011 r. - Prawo geologiczne i górnicze $^{20}$, stanowiący, że koncesja może określać inne wymagania dotyczące wykonywania działalności objętej koncesją, w szczególności w zakresie bezpieczeństwa powszechnego i ochrony środowiska;

16 Dz.U. poz. 1839.

17 Jak stwierdził WSA w Gdańsku w wyroku z dnia 6 kwietnia 2020 r. (sygn. akt II SA/ Gd 131/20): „,dokonując wykładni przepisu art. 82 ust. 1 pkt 1 lit. a ustawy z 2008 r. o udostępnianiu informacji o środowisku i jego ochronie, udziale społeczeństwa w ochronie środowiska oraz o ocenach oddziaływania na środowisko nie można stwierdzić, że organ wydający decyzję o środowiskowych uwarunkowaniach ma obowiązek w treści swojego orzeczenia wskazać konkretne numery działek ewidencyjnych, na których realizowane będzie w przyszłości przedsięwzięcie".

18 Jak stwierdził NSA w wyroku z dnia 14 stycznia 2014 r. (sygn. akt II OSK 1908/12): ,właściwy organ wydający decyzję środowiskową powinien określić warunki przygotowania terenu w zakresie, w jakim szczególnej ochrony wymaga np. cenny las bukowy czy dębowy, rozumiany jako grunt pokryty roślinnością leśną, nie zaś grunt, na którym zgodnie z art. 19 ust. 2 ustawy o lasach, drzewa zostały wycięte przed wszczęciem postępowania o wydanie decyzji o środowiskowych uwarunkowaniach".

19 Dz.U. 2020, poz. 293 ze zm.

20 Dz.U. 2020, poz. 1064 ze zm. 
— art. 11f ust. 1 pkt 3 ustawy z dnia 10 kwietnia 2003 r. o szczególnych zasadach przygotowania i realizacji inwestycji $\mathrm{w}$ zakresie dróg publicznych ${ }^{21}$ pozwalający w decyzji zezwalającej na realizację inwestycji w zakresie dróg publicznych na określenie warunków wynikających z potrzeb ochrony środowiska, ochrony zabytków i dóbr kultury współczesnej oraz potrzeb obronności państwa;

- art. 40 ust. 2 pkt 4 ustawy z dnia 10 maja 2018 r. o Centralnym Porcie Komunikacyjnym ${ }^{22}$ na określenie warunków wynikających $\mathrm{z}$ potrzeb ochrony środowiska, ochrony przeciwpożarowej oraz ochrony zabytków i dóbr kultury. Nie oznacza to oczywiście, że nie mogą one funkcjonować „,W oderwaniu" od pozwolenia na realizację przedsięwzięcia, a ich wykonanie będzie zagwarantowane zagrożeniem egzekucją administracyjną (ewentualnie karą pieniężną).

Analizując treść art. 86 i art. 82 (odpowiednio art. 84 ust. 1a) ustawy o ocenach, można jednak dojść do wniosku, że związanie decyzją o środowiskowych uwarunkowaniach winno następować przede wszystkim na etapie projektowania zamierzenia. Stąd w pełni zasadne jest „związanie” w zakresie dokumentacji wymaganej do wydania decyzji, o których mowa w art. 72 ust. 1, w szczególności w projekcie zagospodarowania działki lub terenu lub projekcie architektoniczno-budowlanym, w przypadku decyzji, o których mowa w art. 72 ust. 1 pkt 1, 10, 14, 18, 23, 26 i 27 (art. 82 ust. 1 pkt 1 lit c ustawy o ocenach). Ustawodawca szczególnie akcentuje tu konieczność uwzględniania środowiskowych uwarunkowań w dokumentacji projektowej niezbędnej do wydania pozwolenia na budowę (decyzji „zastępujących” to pozwolenie). Szczególną rolę będzie tu odgrywał projektant przedsięwzięcia. W dokumentacji projektowej musi zawrzeć nałożone decyzją o środowiskowych uwarunkowaniach obowiązki. Zgodnie z art. 35 ust. 1 pkt 1 lit c ustawy z dnia 7 lipca 1994 r. - Prawo budowlane ${ }^{23}$, ,przed wydaniem decyzji o pozwoleniu na budowę lub odrębnej decyzji o zatwierdzeniu projektu zagospodarowania działki lub terenu oraz projektu architektoniczno-budowlanego organ administracji architektoniczno-budowlanej sprawdza [...] zgodność projektu zagospodarowania działki lub terenu oraz projektu architektoniczno-budowlanego z [...] wymaganiami ochrony środowiska, w szczególności określonymi w decyzji o środowiskowych uwarunkowaniach, o której mowa w art. 71 ust. 1 ustawy z dnia 3 października 2008 r. o udostępnianiu informacji o środowisku i jego ochronie, udziale społeczeństwa w ochronie środowiska oraz o ocenach oddziaływania na środowisko".

Należy mieć jednak świadomość, że praktycznie wszystkie pozwolenia na realizację przedsięwzięcia, o których mowa w art. 72 ust. 1 ustawy o ocenach, są wydawane w oparciu o uprzednio przygotowaną dokumentację, która wy-
${ }^{21}$ Dz.U. 2020, poz. 1363
22 Dz.U. 2020, poz. 234.
${ }^{23}$ Dz.U. 2020, poz. 1333 ze zm. 
magania przewidziane w decyzji o środowiskowych uwarunkowaniach będzie musiała uwzględniać.

Poza środowiskowymi uwarunkowaniami ściśle związanymi z wydaniem decyzji „inwestycyjnej” należy zwrócić uwagę, iż decyzja, o której mowa w art. 71 ustawy o ocenach, zawiera (bądź może zawierać) inne nakazy czy zakazy. Można tu wskazać:

- wymogi w zakresie przeciwdziałania skutkom awarii przemysłowych, w odniesieniu do przedsięwzięć zaliczanych do zakładów stwarzających zagrożenie wystąpienia poważnych awarii w rozumieniu ustawy z dnia 27 kwietnia 2001 r. - Prawo ochrony środowiska ${ }^{24}$;

- wymogi w zakresie ograniczania transgranicznego oddziaływania na środowisko w odniesieniu do przedsięwzięć, dla których przeprowadzono postępowanie w sprawie transgranicznego oddziaływania na środowisko;

- gotowość instalacji do wychwytywania dwutlenku węgla w przypadku instalacji do spalania paliw w celu wytwarzania energii elektrycznej, o elektrycznej mocy znamionowej nie mniejszej niż $300 \mathrm{MW}^{25}$.

Warunki powyższe, jak się wydaje, mogą częściowo zostać „implementowane" do pozwolenia na realizację przedsięwzięcia, a częściowo ich realizacja będzie następować bezpośrednio w oparciu o decyzję o środowiskowych uwarunkowaniach.

24 Dz.U. 2020, poz. 1219 ze zm.

25 Zobowiązanie dotyczące możliwości wychwytywania przez instalację $\mathrm{CO}_{2}$ wydaje się obowiązkiem niemającym uzasadnienia. Jedyną dostępną obecnie metodą postępowania $\mathrm{z}$ tym gazem jest jego geologiczne składowanie. Prawo polskie nie dopuszcza zaś możliwości komercyjnego składowania $\mathrm{CO}_{2}$. Wynika to bezpośrednio z art. 21 ust. la ustawy Prawo geologiczne i górnicze, zgodnie z którym ,zabrania się wykonywania działalności polegającej na poszukiwaniu lub rozpoznawaniu kompleksu podziemnego składowania dwutlenku węgla albo na podziemnym składowaniu dwutlenku węgla w celu innym niż przeprowadzenie projektu demonstracyjnego wychwytu i składowania dwutlenku węgla”. Projektem demonstracyjnym jest zaś (art. 1 ust. 3 ustawy Prawo geologiczne i górnicze), ,przedsięwzięcie polegające na wychwytywaniu, przesyłaniu i podziemnym składowaniu dwutlenku węgla, spełniające kryteria dotyczące projektów demonstracyjnych określone w decyzji Komisji nr 2010/670/UE z dnia 3 listopada 2010 r. ustanawiającej kryteria i środki dotyczące finansowania komercyjnych projektów demonstracyjnych mających na celu bezpieczne dla środowiska wychwytywanie i geologiczne składowanie $\mathrm{CO}_{2}$ oraz projektów demonstracyjnych w zakresie innowacyjnych technologii energetyki odnawialnej realizowanych w ramach systemu handlu uprawnieniami do emisji gazów cieplarnianych we Wspólnocie, ustanowionego dyrektywą Parlamentu Europejskiego i Rady 2003/87/WE (Dz Urz. UE L 290 z dnia 6 listopada 2010 r., s. 39), które jest realizowane w celu sprawdzenia:

1) skuteczności i przydatności stosowania technologii wychwytu i składowania $\mathrm{CO}_{2} \mathrm{~W}$ zakresie ograniczenia emisji $\mathrm{CO}_{2}$;

2) bezpieczeństwa stosowania technologii wychwytu i składowania $\mathrm{CO}_{2}$ dla zdrowia i życia ludzi oraz dla środowiska;

3) potrzeby i zasadności dopuszczenia do stosowania technologii wychwytu i składowania $\mathrm{CO}_{2}$ na skalę przemysłową. 
Inaczej problem „związania” decyzją o środowiskowych uwarunkowaniach przedstawia się w przypadku elementów decyzji wskazanych w art. 82 ust. 1 pkt 2 ustawy o ocenach. Dotyczy to sytuacji, gdy z oceny oddziaływania przedsięwzięcia na środowisko wynika potrzeba:

— wykonania kompensacji przyrodniczej — stwierdza konieczność wykonania tej kompensacji;

- unikania, zapobiegania, ograniczania oddziaływania przedsięwzięcia na środowisko - nakłada obowiązek tych działań;

- monitorowania oddziaływania przedsięwzięcia na środowisko - nakłada obowiązek monitorowania, określając jego zakres, termin i obowiązki co do przedłożenia informacji o jego wynikach regionalnemu dyrektorowi ochrony środowiska, organowi wydającemu decyzję o środowiskowych uwarunkowaniach oraz, gdy jest to uzasadnione, wskazuje inne organy ochrony środowiska, którym należy przedłożyć wyniki monitoringu.

W wyżej wymienionych przypadkach „związanie” decyzją o środowiskowych uwarunkowaniach będzie miało charakter bezpośredni (bez implementacji obowiązków do decyzji o środowiskowych uwarunkowaniach), a zobowiązanym będzie inwestor.

Decyzja o środowiskowych uwarunkowaniach zawiera (może zawierać) jeszcze kilka rozstrzygnięć, które wiążą bądź inwestora bądź inne organy w dość zróżnicowany sposób.

Należy przede wszystkim zwrócić uwagę na art. 82 ust. 1 pkt 3 ustawy o ocenach, zgodnie z którym organ właściwy do wydania decyzji o środowiskowych uwarunkowaniach jest uprawniony do „stwierdzenia konieczności utworzenia obszaru ograniczonego użytkowania” ${ }^{26}$. Pojawia się pytanie, czy stwierdzenie „konieczności” utworzenia takiego obszaru jest równoznaczne z powstaniem odpowiedniego obowiązku. Niezależnie od tego obszar ograniczonego użytkowania tworzą odpowiednio rada powiatu i sejmik województwa. Zatem to te organy byłyby „związane” decyzją o środowiskowych uwarunkowaniach. Trudno jednak wyobrazić sobie mechanizm, który mógłby wymusić realizację tak rozumianego „obowiązku”.

W decyzji o środowiskowych uwarunkowaniach organ ją wydający przedstawia również stanowisko w sprawie konieczności przeprowadzenia oceny oddziaływania przedsięwzięcia na środowisko oraz postępowania w sprawie transgranicznego oddziaływania na środowisko $\mathrm{w}$ ramach postępowania $\mathrm{w}$ sprawie wydania decyzji, o których mowa w art. 72 ust. 1 pkt 1, 10, 14 i 18, z zastrzeże-

${ }^{26}$ Nakładając jednocześnie obowiązek wykonania analizy porealizacyjnej, określając jej zakres i termin przedstawienia oraz wskazując inne organy, którym także należy ją przedstawić. 
niem pkt $4 a^{27}$ i $4 b^{28}$; nie dotyczy to inwestycji w zakresie terminalu. Na gruncie tego przepisu pojawia się pytanie, czym z punktu widzenia prawa jest stanowisko (pozytywne lub negatywne ${ }^{29}$ ) dotyczące przeprowadzenia ponownej oceny oddziaływania na środowisko. Należy przyjąć, że wiąże ono organy wydające decyzje, o których mowa w art. 72 ust. 1 pkt 1, 10, 14 i 18 ustawy o ocenach. Zatem $\mathrm{w}$ ramach postępowania $\mathrm{w}$ sprawie wydania jednego $\mathrm{z}$ wyżej wymienionych aktów będą musiały przeprowadzić ponowną ocenę oddziaływania na środowisko.

Decyzją o środowiskowych uwarunkowaniach (art. 82 ust. 1 pkt 5 ustawy o ocenach) można wreszcie nałożyć wnioskodawcę (inwestora) obowiązek przedstawienia analizy porealizacyjnej, określając jej zakres i termin przedstawienia oraz wskazując inne organy, którym także należy ją przedstawić. Rozstrzygnięcie w tym zakresie jest fakultatywne. Jak stwierdził WSA w Poznaniu w wyroku z dnia 10 sierpnia 2016 r. (sygn. akt IV SA/Po 107/16) ,użyte przez ustawodawcę w art. 82 ust. 1 pkt 5 ustawy z 2008 r. o udostępnianiu informacji o środowisku i jego ochronie, udziale społeczeństwa w ochronie środowiska oraz o ocenach oddziaływania na środowisko sformułowanie »może« wskazuje, że od uznania właściwego organu administracji zależy, czy taki obowiązek nałoży na Inwestora. Powyższe nie oznacza oczywiście dowolności po stronie organu, bowiem nakłada obowiązek uzasadnienia zajętego stanowiska".

4. Przeprowadzona analiza treści i zakresu mocy wiążącej decyzji o środowiskowych uwarunkowaniach pozwala na wyciągnięcie kilku wniosków. Przede wszystkim łatwo dostrzec, że wspomniany akt co do zakresu jego rozstrzygnięcia ewoluował. Przy czym ewolucja ta powoduje zwiększenie zakresu spraw nim regulowanych. Pierwotnie treść omawianej decyzji ograniczała się do wyników przeprowadzonej oceny oddziaływania na środowisko. Obecnie stanowi

${ }^{27}$ Organ nakłada obowiązek przeprowadzenia oceny oddziaływania przedsięwzięcia na środowisko w ramach postępowania w sprawie wydania pozwolenia na budowę dla inwestycji w zakresie budowy obiektu energetyki jądrowej lub inwestycji jej towarzyszącej, o których mowa w ustawie z dnia 29 czerwca 2011 r. o przygotowaniu i realizacji inwestycji w zakresie obiektów energetyki jądrowej oraz inwestycji towarzyszących.

${ }^{28}$ Organ może nałożyć obowiązek przeprowadzenia oceny oddziaływania przedsięwzięcia na środowisko $\mathrm{w}$ ramach postępowania w sprawie wydania pozwolenia na prace przygotowawcze, o których mowa w ustawie z dnia 29 czerwca 2011 r. o przygotowaniu i realizacji inwestycji w zakresie obiektów energetyki jądrowej oraz inwestycji towarzyszących.

${ }^{29}$ Nie wydaje się trafne stanowisko prezentowane w orzecznictwie sądów administracyjnych, że „nie sposób uznać, iż przedstawienie stanowiska w sprawie konieczności przeprowadzenia oceny oddziaływania przedsięwzięcia na środowisko winno być obligatoryjne, w sytuacji gdy organ nie znajduje uzasadnienia dla konieczności przeprowadzenia ponownej oceny oddziaływania na środowisko" (por. wyrok NSA z dnia 21 marca 2012 r., sygn. akt II OSK 2579/10). Redakcja art. 82 ust. 1 pkt 4 wskazuje, że stanowisko takie powinno zostać przedstawione w osnowie decyzji środowiskowej, przy czym może być ono „pozytywne” lub „negatywne”. 
ona kompleksowy akt regulujący kwestie tak odległe, jak obowiązek utworzenia obszaru ograniczonego użytkowania czy gotowość instalacji do wychwytywania dwutlenku węgla. To bezpośrednio wiąże się z zakresem związania decyzją o środowiskowych uwarunkowaniach. Nie jest już to tylko organ wydający pozwolenie na realizację przedsięwzięcia, ale również inne organy, w tym stanowiące jednostki samorządu terytorialnego.

Trudno w chwili obecnej stwierdzić, czy postępująca ewolucja decyzji, o której mowa w art. 72 ust. 1 ustawy o ocenach, jest zjawiskiem pozytywnym. $\mathrm{Z}$ jednej strony można bowiem podnieść argument, że istnienie wspomnianego „superaktu” w zakresie podejmowania działalności negatywnie wpływającej na środowisko pozwoli w sposób kompleksowy reglamentować to oddziaływanie. Nie można jednak tracić z oczu pierwotnej roli, jaką miała odgrywać decyzja o środowiskowych uwarunkowaniach. Miała ona zawierać wynik przeprowadzonej oceny oddziaływania przedsięwzięcia na środowisko. Objęcie nią innych aspektów, w szczególności związanych z eksploatacją przedsięwzięcia może prowadzić do ograniczenia wspomnianej pierwotnej roli omawianej decyzji, co może zaś prowadzić do osłabienia prewencyjnej funkcji ocen oddziaływania na środowisko.

\section{Literatura}

Dobrowolski G., Decyzja o środowiskowych uwarunkowaniach, Towarzystwo Naukowe Organizacji i Kierownictwa „Dom Organizatora”, Toruń 2011.

Dobrowolski G., Lipiński A., Mikosz R., Radecki G., Gospodarowanie geologicznymi zasobami środowiska w świetle zasady zrównoważonego rozwoju. Zagadnienia prawne, Wydawnictwo Uniwersytetu Śląskiego, Katowice 2018.

Kosieradzka-Fedrczyk A., Decyzje o środowiskowych uwarunkowaniach oraz ich wykonalność i wykonanie. Analiza prawna, „Przegląd Prawa Ochrony Środowiska” 2013, nr 2, s. 47-67.

Otawski P., Decyzja o środowiskowych uwarunkowaniach — relacja do innych decyzji w toku realizacji i eksploatacji przedsięwzięcia, w: Proces inwestycji budowlanych, red. A. Plucińska-Filipowicz, M. Wierzbowski, Wolters Kluwer, Warszawa 2015, s. 193-206.

Pchałek M., Behnke M., Postepowanie w sprawie oceny oddziaływania na środowisko w prawie polskim i UE, Wydawnictwo C.H.Beck, Warszawa 2009.

Sadowski P., Lebowa D., Administracyjnoprawne ograniczenia realizacji przedsięwzięć wynikajace z konieczności uzyskania decyzji środowiskowej, „Annales Universitatis Mariae Curie-Skłodowska, sectio G (Ius)” 2017, nr 1, s. 125-136.

Wiśniewski Z., Decyzja o środowiskowych uwarunkowaniach w świetle orzecznictwa sądowoadministracyjnego i standardów unijnych, w: „Europeizacja prawa ochrony środowiska”, red. M. Rudnicki, A. Haładyj, K. Sobieraj, Wydawnictwo KUL, Lublin 2011, s. 85-118.

Trzcińska D., Charakter prawny decyzji o środowiskowych uwarunkowaniach zgody na realizację przedsięwzięcia, „Studia Prawnoustrojowe” 2017, nr 37, s. 78. 
Grzegorz Dobrowolski

\title{
The problem of "binding" of the decision on environmental conditions
}

\begin{abstract}
Summary
The article is devoted to the problem of "binding" with the content of decisions on environmental conditions. It specifies not only the environmental conditions for the implementation of the project, but also other obligations in the field of environmental protection.
\end{abstract}

Keywords: Environmental protection, decision on environmental conditions

Гжегож Добровольский

\section{Проблема «связывания» решением об экологических условиях}

\section{Резюме}

В статье рассматривается проблема «связывания» содержанием решений об экологических условиях. Она описывает не только экологические условия реализации проекта, но и другие обязательства в области охраны окружающей среды.

Ключевые слова: Охрана окружающей среды, решение об экологических условиях

Grzegorz Dobrowolski

\section{Il problema di "vincolare" la decisione alle condizioni ambientali}

\section{Sommario}

Questo articolo è dedicato al problema del "vincolo" dal contenuto della decisione sulle condizioni ambientali. Determina non solo le condizioni ambientali per la realizzazione del progetto, ma anche altri obblighi nel campo della protezione ambientale.

Parole chiave: Protezione dell'ambiente, decisione sulle condizioni ambientali 